\title{
Financial Level of Czech and Slovak Employees*
}

\author{
Diana Bílková \\ University of Economics, Prague, Czech Republic \\ University of Finance and Administration, Prague, Czech Republic
}

\begin{abstract}
This paper deals with the development of wage distribution by gender in the Czech and Slovak Republics in the years of 2005-2012. Special attention is given to changes in the behavior of wage distribution in relation to the onset of the global economic recession. The different behavior of the wage distribution of Czech and Slovak employees during the period is the subject of research. The article discusses the differences in the wage level between men and women in the Czech and Slovak Republics. There are the total wage distributions of men and women together, both in the Czech Republic and in the Slovak Republic on one hand, and wage distributions according to the gender separately for men and women on the other hand. Special attention was paid to the development of Gini coefficient of the concentration in both countries according to the gender in the period under review, too.
\end{abstract}

Keywords: wage distribution by gender, financial crisis, wages of Czech and Slovak employees, Gini coefficient of concentration, forecasts of wage distribution

\section{Introduction}

Development of the wages of Czech and Slovak employees in the last two decades requires us to pay more attention to the issues of their differentiation in the research. This leads to strong changes in this area. As wage structure of the population changes, the level and differentiation grow. Groups of people with very high wages arise here and they are gradually becoming more pronounced. In the research of wage differentiation, it is not enough to focus only on the assessment of the current situation and forecast future development based on the average wage broken down by different socio-economic, time-spatial, and demographic considerations, but it is helpful to move from the level characteristics to the whole of frequency distribution.

Considerable attention is paid to wage and income distribution in the statistical literature. A number of authors in the Czech and Slovak Republics dealt with the analysis of wage and income distribution (Bílková, 2012a; 2012b; Marek, 2010; 2013; Marek \& Vrabec, 2013; 2014). Many other methods may be used when analyzing economic data and also in the analysis of wage distribution (Löster \& Pavelka, 2013; L. Malec \& M. Malec, 2013; Pivoňka \& Löster, 2013; Řezanková \& Löster, 2013). The development of a wide range of other indicators of the national economy is related to the development of wage (Löster \& Langhamrová, 2011; 2012).

\footnotetext{
* Acknowledgment: This paper was subsidized by the funds of institutional support of a long-term conceptual advancement of science and research number IP400040 at the Faculty of Informatics and Statistics, University of Economics, Prague, Czech Republic.

Diana Bílková, associate professor, Department of Statistics and Probability, Faculty of Informatics and Statistics, University of Economics; associate professor, Department of Informatics and Mathematics, Faculty of Economic Studies, University of Finance and Administration. Email: bilkova@vse.cz; diana.bilkova@vsfs.cz.
} 
The theoretical nature of the methods used in this article is not described here. Used descriptive characteristics of wage distribution are explained, for example, in Triola (2003). Three-parametric lognormal curves are the basic model distribution. The nature of lognormal curves is explained, for example, in Bílková (2012a; 2012b). Method of L-moments was used when estimating the parameters of these curves, see Hosking and Wallis (1997) or Kyselý and Picek (2007).

\section{Database}

Processed data come from the official websites of the Czech Statistical Office and the Statistical Office of the Slovak Republic. There are data in the form of the interval frequency distribution with open extreme intervals. The researched variable is the gross monthly wage in EUR. Conversions from CZK to EUR and SKK to EUR (2005-2008) were made using the exchange rate to half of that calendar year (see Table 1).

Table 1

Exchange Rates in the Middle of a Calendar Year

\begin{tabular}{lllllllll}
\hline \multirow{2}{*}{ Exchange rate } & \multicolumn{10}{c}{ Date } \\
\cline { 2 - 8 } & July 1, 2005 & June 30, 2006 June 29, 2007 July 1, 2008 & July 1, 2009 & July 1, 2010 & July 1, 2011 & June 29, 2012 \\
\hline CZK/1 EUR & 30.000 & 28.495 & 28.715 & 23.825 & 25.775 & 25.760 & 24.315 & 25.640 \\
SKK/100 CZK & 78.153 & 74.302 & 85.360 & 78.902 & - & - & - & - \\
\hline
\end{tabular}

Note. Source: http://www.cnb.cz.

Because the focus of research is the nominal wage, Table 2 presents the development of average annual rate of inflation in both countries during the period. Since the level of minimum wage markedly affects the wage distribution, Table 2 also provides an idea of the development of minimum wage in both states in the research period.

Table 2

Minimum Wage (in EUR), Unemployment Rate (in \%), Average Annual Inflation Rate (in \%), and GDP at Current Prices Calculated by Income Approach (in Mil. EUR)

\begin{tabular}{|c|c|c|c|c|c|c|c|c|}
\hline \multirow[b]{2}{*}{ Year } & \multicolumn{4}{|c|}{ Czech Republic } & \multicolumn{4}{|c|}{ Slovak Republic } \\
\hline & $\begin{array}{l}\text { Minimum } \\
\text { wage }\end{array}$ & $\begin{array}{l}\text { Unemployment } \\
\text { rate }\end{array}$ & $\begin{array}{l}\text { Inflation } \\
\text { rate }\end{array}$ & GDP & $\begin{array}{l}\text { Minimum } \\
\text { wage }\end{array}$ & $\begin{array}{l}\text { Unemployment } \\
\text { rate }\end{array}$ & $\begin{array}{l}\text { Inflation } \\
\text { rate }\end{array}$ & GDP \\
\hline 2005 & 239.5 & 7.9 & 1.9 & $103,868.5$ & $169.3^{1}$ & 16.2 & 2.7 & $49,315.2$ \\
\hline 2006 & $\begin{array}{l}265.7^{2} \\
279.2^{3}\end{array}$ & 7.1 & 2.5 & $117,655.7$ & $179.9^{4}$ & 13.3 & 4.5 & $55,081.9$ \\
\hline 2007 & 278.6 & 5.3 & 2.8 & $127,549.1$ & $225.9^{5}$ & 11.0 & 2.8 & $61,501.1$ \\
\hline 2008 & 335.8 & 4.4 & 6.3 & $161,528.3$ & 268.3 & 9.6 & 4.6 & $66,842.3$ \\
\hline 2009 & 310.4 & 6.7 & 1.0 & $145,838.2$ & 295.5 & 12.1 & 1.6 & $62,794.4$ \\
\hline 2010 & 310.6 & 7.3 & 1.5 & $147,161.5$ & 307.7 & 14.4 & 1.0 & $65,869.5$ \\
\hline 2011 & 329.0 & 6.7 & 1.9 & $157,244.5$ & 317.0 & 13.5 & 3.9 & $69,108.3$ \\
\hline 2012 & 312.0 & 7.0 & 3.3 & $149,997.1$ & 327.2 & 14.0 & 3.6 & $71,463.0$ \\
\hline
\end{tabular}

Note. Source: http://www.czso.cz; http://portal.statistics.sk; own research.

\footnotetext{
${ }^{1}$ From October 1, 2004 to October 1, 2005.

${ }^{2}$ From January 1, 2006 to June 30, 2006.

${ }^{3}$ From July 1, 2006 to December 31, 2006.

${ }^{4}$ From October 1, 2005 to October 1, 2006.

5 From October 1, 2006 to October 1, 2007.
} 
In 2013, the minimum wage is 312.0 EUR in the Czech Republic and 337.7 EUR in the Slovak Republic. As the wage development is strongly tied to the development of such indicators as unemployment rate and GDP, Table 2 provides an overview of the development of these indicators for comparison. Figures 1 and 2 show the growth rate of GDP in the period.

Data were processed using the spreadsheet Microsoft Excel and statistical program package Statgraphics.

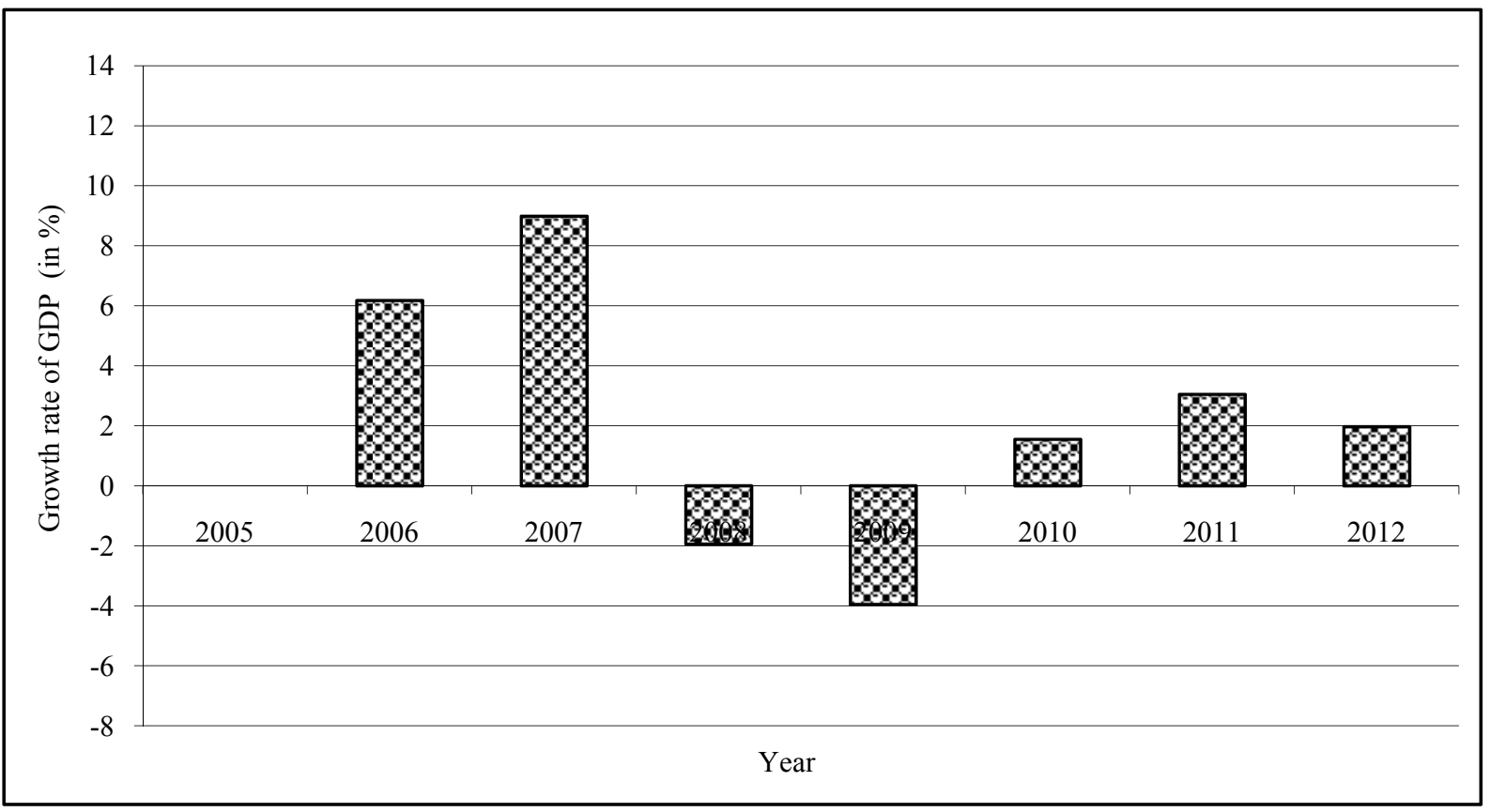

Figure 1. Growth rate of GDP at market prices (in \%) in the Czech Republic in the period of 2005-2012. Source: http://epp.eurostat.ec.europa.eu.

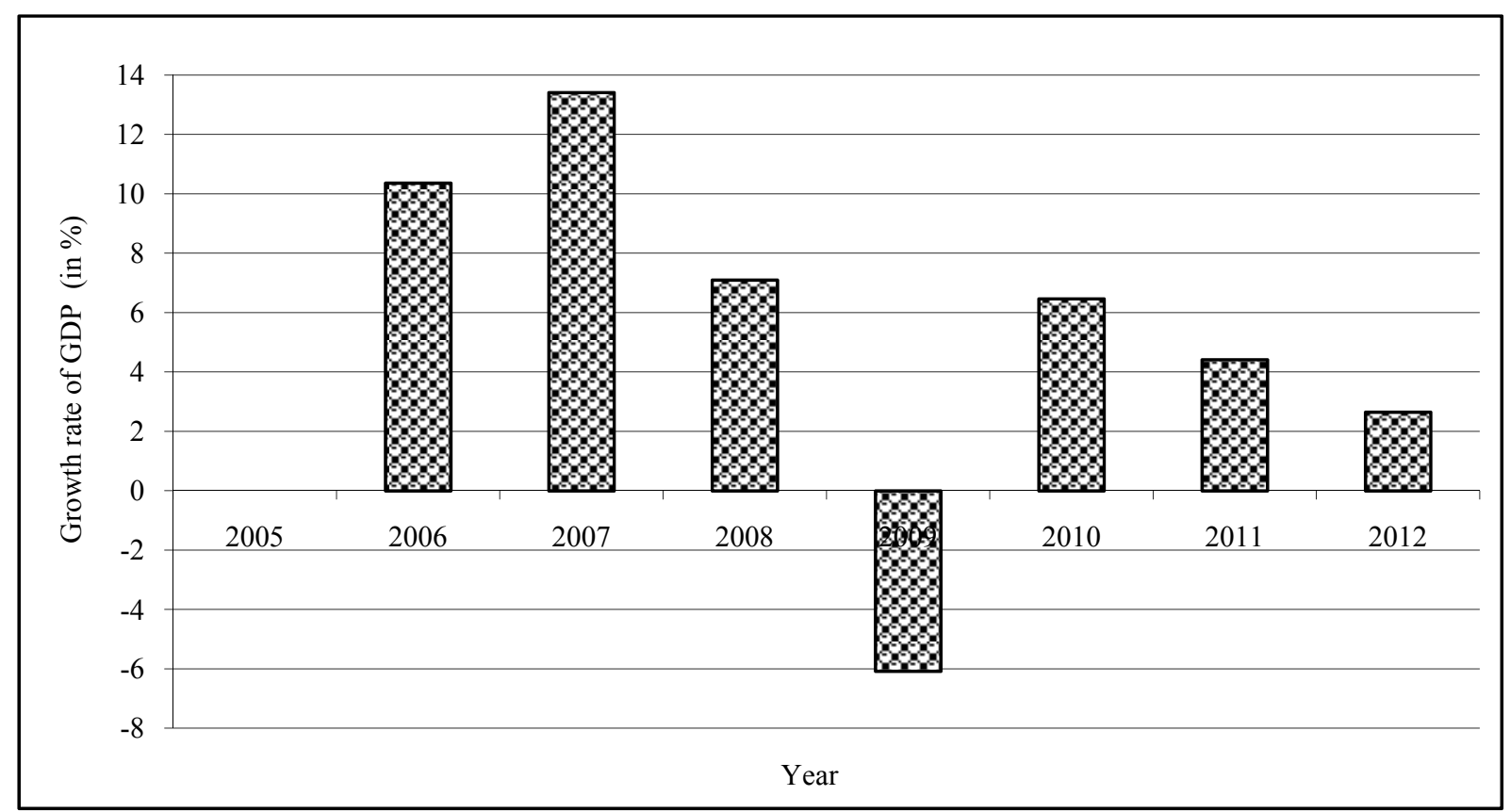

Figure 2. Growth rate of GDP at market prices (in \%) in the Slovak Republic in the period of 2005-2012. Source: $\mathrm{http}: / /$ epp.eurostat.ec.europa.eu. 


\section{Comparison of the Development of Wage Level in the Czech and Slovak Republics}

Figure 3 shows the development of location characteristics of total wage distribution (for men and women together) in the Czech and Slovak Republics in the research period of 2005-2012 including forecasts for 2013 and 2014. Figures 4 and 5 show the same thing, but for men and women separately. Tables 3 and 4 represent growth annual coefficients and average growth annual coefficients of the arithmetic mean, median, and medial of gross monthly wage in the period of 2005-2012 including predictions for 2013 and 2014 in the Czech and Slovak Republics by gender.

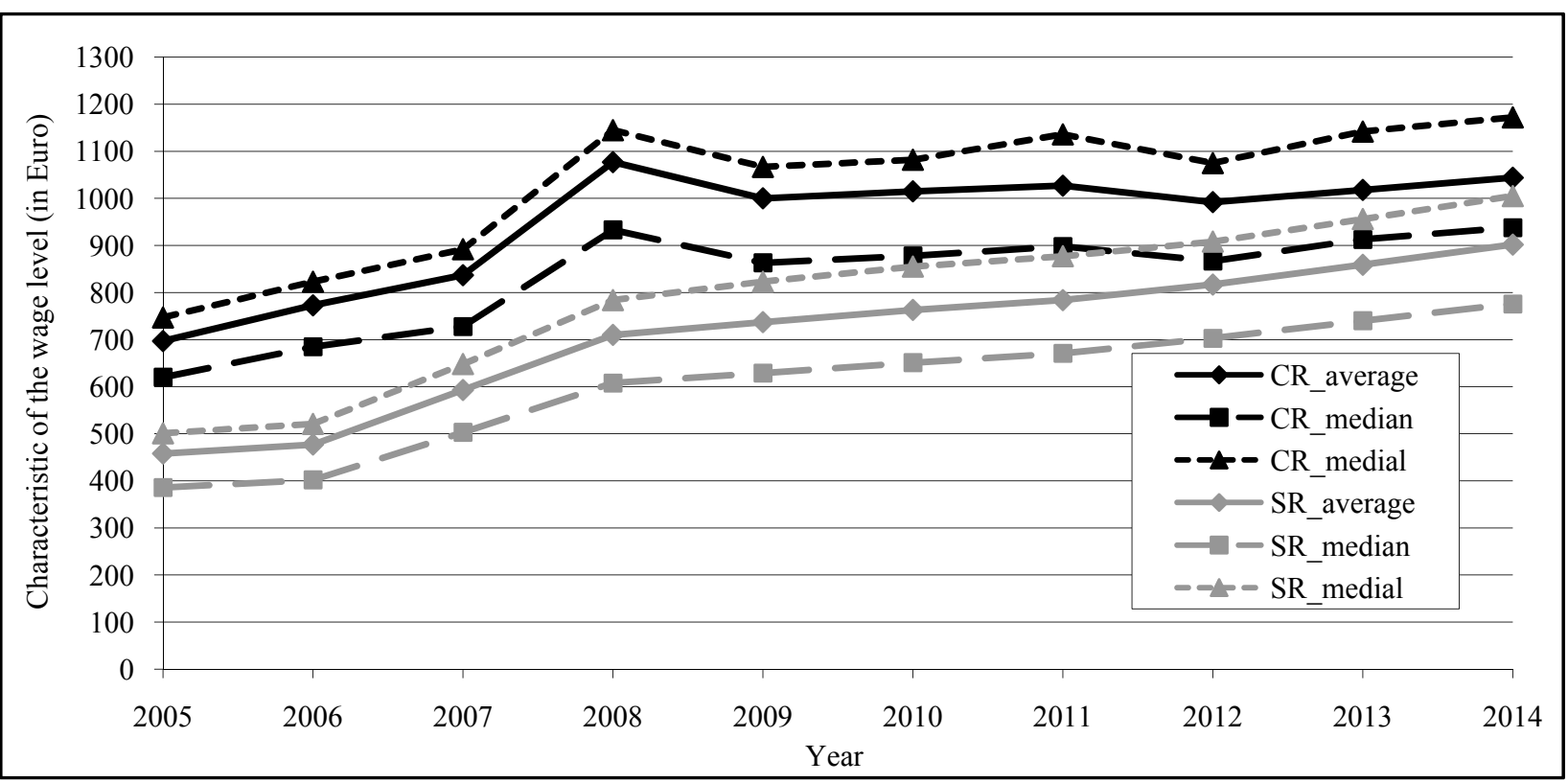

Figure 3. Development of location characteristics of wage distribution of Czech and Slovak employees (total set) between 2005 and 2012 including predictions for 2013 and 2014. Source: Own research.

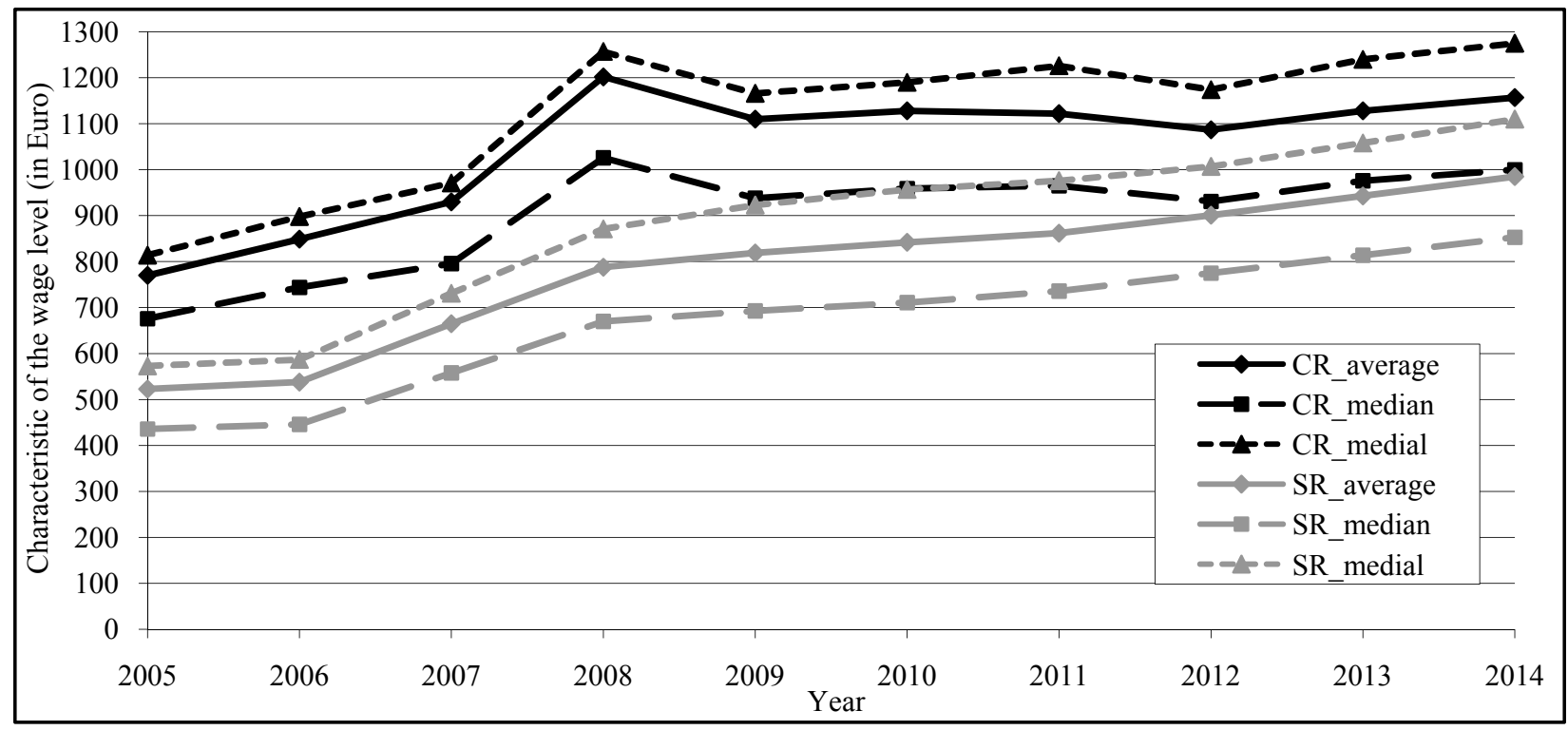

Figure 4. Development of location characteristics of wage distribution of Czech and Slovak employees (set of men) between 2005 and 2012 including predictions for 2013 and 2014. Source: Own research. 
Medial is such a characteristic of wage level that workers with wages less than or equal to medial get half of the total amount of wages and workers with wages greater than or equal to medial get the other half of the total amount of wages.

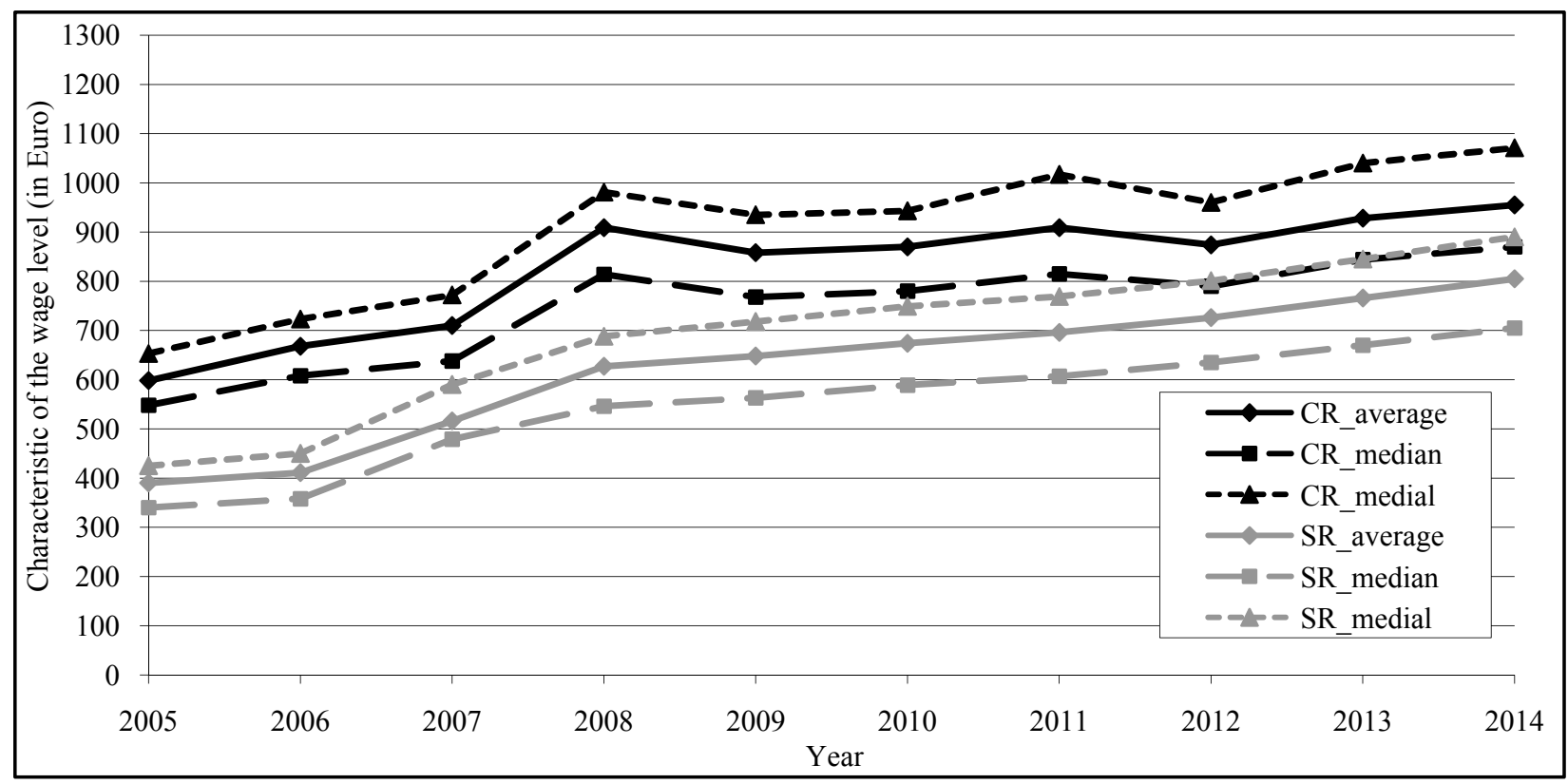

Figure 5. Development of location characteristics of wage distribution of Czech and Slovak employees (set of women) between 2005 and 2012 including predictions for 2013 and 2014. Source: Own research.

Comparison of the development of wage level between the Czech and Slovak Republics is interesting. While in the first year of the financial crisis in 2009, we record an appreciable drop in the wage level in the Czech Republic, in terms of both total wage distribution for men and women together and separate wage distribution individually for men and women, wages in the Slovak Republic in 2009 continue to grow, even though they are far below the growth rate before the financial crisis (see Figures 3-5 and Tables 3-4).

We can see a similar drop in the wage level in the Czech Republic in 2012, unlike the Slovak Republic, where wage increases in this year. We can say that wage growth in the Czech Republic has virtually stopped during the global economic crisis, while the Slovak wage also grows in the period of financial recession, despite that they are far below the growth rate before the financial crisis. However, we must remember that it is a recalculation of CZK to EUR in terms of the Czech Republic, and therefore, the results can be affected by exchange rate CZK/EUR. The same problem arises in terms of the Slovak Republic at the beginning of the research period. However, it can be assumed that wage development is very closely tied to the development of GDP. We can see from Figures 1 and 2 that the Slovak Republic evinces more positive development of GDP in 2010 of the financial crisis than the Czech Republic. Figures 3-5 also show a strongly higher wage level in the Czech Republic compared to the wage level in the Slovak Republic. The obtained results also show that although the development of wage level in the Czech Republic during the world economic crisis shows an average annual decline and the development of wage level in the Slovak Republic in this period shows an average annual growth, the level of nominal wage in the Slovak Republic is still markedly below the nominal wage in the Czech Republic now. However, Figure 6 shows that the difference between the wage level in the Czech Republic and the Slovak Republic is decreasing with time. 
Table 3

Growth Annual Coefficients and Average Growth Annual Coefficients of Arithmetic Mean, Median, and Medial of Gross Monthly Wage in the Period of 2005-2012 Including Predictions for 2013 and 2014 in the Czech Republic by Gender

\begin{tabular}{|c|c|c|c|c|c|c|c|c|c|}
\hline \multirow[b]{2}{*}{ Year } & \multicolumn{3}{|c|}{ Total } & \multicolumn{3}{|c|}{ Men } & \multicolumn{3}{|c|}{ Women } \\
\hline & $\begin{array}{l}\text { Arithm. } \\
\text { mean }\end{array}$ & Median & Medial & $\begin{array}{l}\text { Arithm. } \\
\text { mean }\end{array}$ & Median & Medial & $\begin{array}{l}\text { Arithm. } \\
\text { mean }\end{array}$ & Median & Medial \\
\hline 2005 & - & - & - & - & - & - & - & - & - \\
\hline 2006 & 1.109 & 1.105 & 1.102 & 1.103 & 1.101 & 1.103 & 1.117 & 1.109 & 1.107 \\
\hline 2007 & 1.083 & 1.063 & 1.084 & 1.095 & 1.070 & 1.081 & 1.063 & 1.049 & 1.068 \\
\hline 2008 & 1.287 & 1.282 & 1.284 & 1.292 & 1.289 & 1.295 & 1.280 & 1.276 & 1.271 \\
\hline 2009 & 0.929 & 0.925 & 0.932 & 0.923 & 0.914 & 0.928 & 0.944 & 0.943 & 0.953 \\
\hline 2010 & 1.015 & 1.017 & 1.014 & 1.016 & 1.022 & 1.021 & 1.014 & 1.016 & 1.009 \\
\hline 2011 & 1.012 & 1.023 & 1.050 & 0.995 & 1.006 & 1.030 & 1.045 & 1.045 & 1.078 \\
\hline 2012 & 0.966 & 0.965 & 0.946 & 0.969 & 0.965 & 0.958 & 0.961 & 0.969 & 0.944 \\
\hline 2013 & 1.026 & 1.053 & 1.062 & 1.038 & 1.048 & 1.056 & 1.062 & 1.068 & 1.083 \\
\hline 2014 & 1.109 & 1.105 & 1.102 & 1.103 & 1.101 & 1.103 & 1.117 & 1.109 & 1.107 \\
\hline Ø 2005-2008 & 1.156 & 1.146 & 1.153 & 1.160 & 1.149 & 1.156 & 1.150 & 1.141 & 1.145 \\
\hline Ø 2008-2012 & 0.980 & 0.982 & 0.984 & 0.975 & 0.976 & 0.983 & 0.990 & 0.993 & 0.995 \\
\hline Ø 2005-2012 & 1.052 & 1.049 & 1.053 & 1.050 & 1.047 & 1.054 & 1.056 & 1.054 & 1.057 \\
\hline Ø 2012-2014 & 1.026 & 1.040 & 1.044 & 1.032 & 1.036 & 1.042 & 1.045 & 1.049 & 1.056 \\
\hline Ø 2005-2014 & 1.046 & 1.047 & 1.051 & 1.046 & 1.044 & 1.051 & 1.053 & 1.053 & 1.057 \\
\hline
\end{tabular}

Note. Source: Own research.

Table 4

Growth Annual Coefficients and Average Growth Annual Coefficients of Arithmetic Mean, Median, and Medial of Gross Monthly Wage in the Period of 2005-2012 Including Predictions for 2013 and 2014 in the Slovak Republic by Gender

\begin{tabular}{|c|c|c|c|c|c|c|c|c|c|}
\hline \multirow[b]{2}{*}{ Year } & \multicolumn{3}{|c|}{ Total } & \multicolumn{3}{|c|}{ Men } & \multicolumn{3}{|c|}{ Women } \\
\hline & $\begin{array}{l}\text { Arithm. } \\
\text { mean }\end{array}$ & Median & Medial & $\begin{array}{l}\text { Arithm. } \\
\text { mean }\end{array}$ & Median & Medial & $\begin{array}{l}\text { Arithm. } \\
\text { mean }\end{array}$ & Median & Media \\
\hline 2005 & - & - & - & - & - & - & - & - & - \\
\hline 2006 & 1.041 & 1.041 & 1.040 & 1.029 & 1.023 & 1.024 & 1.054 & 1.053 & 1.059 \\
\hline 2007 & 1.243 & 1.251 & 1.244 & 1.236 & 1.251 & 1.245 & 1.255 & 1.338 & 1.311 \\
\hline 2008 & 1.197 & 1.209 & 1.210 & 1.185 & 1.201 & 1.192 & 1.215 & 1.140 & 1.166 \\
\hline 2009 & 1.038 & 1.035 & 1.050 & 1.039 & 1.034 & 1.060 & 1.033 & 1.031 & 1.044 \\
\hline 2010 & 1.035 & 1.035 & 1.039 & 1.028 & 1.026 & 1.037 & 1.040 & 1.046 & 1.043 \\
\hline 2011 & 1.028 & 1.031 & 1.026 & 1.024 & 1.035 & 1.020 & 1.033 & 1.031 & 1.027 \\
\hline 2012 & 1.042 & 1.048 & 1.035 & 1.045 & 1.053 & 1.032 & 1.043 & 1.046 & 1.042 \\
\hline 2013 & 1.051 & 1.053 & 1.053 & 1.047 & 1.050 & 1.051 & 1.055 & 1.055 & 1.055 \\
\hline 2014 & 1.041 & 1.041 & 1.040 & 1.029 & 1.023 & 1.024 & 1.054 & 1.053 & 1.059 \\
\hline Ø 2005-2008 & 1.157 & 1.164 & 1.161 & 1.146 & 1.154 & 1.150 & 1.171 & 1.171 & 1.174 \\
\hline Ø 2008-2012 & 1.036 & 1.037 & 1.037 & 1.034 & 1.037 & 1.037 & 1.037 & 1.038 & 1.039 \\
\hline Ø 2005-2012 & 1.086 & 1.089 & 1.089 & 1.081 & 1.086 & 1.084 & 1.093 & 1.093 & 1.095 \\
\hline Ø 2012-2014 & 1.051 & 1.051 & 1.052 & 1.046 & 1.049 & 1.050 & 1.053 & 1.054 & 1.054 \\
\hline Ø 2005-2014 & 1.078 & 1.081 & 1.080 & 1.073 & 1.077 & 1.076 & 1.084 & 1.084 & 1.086 \\
\hline
\end{tabular}

Note. Source: Own research. 


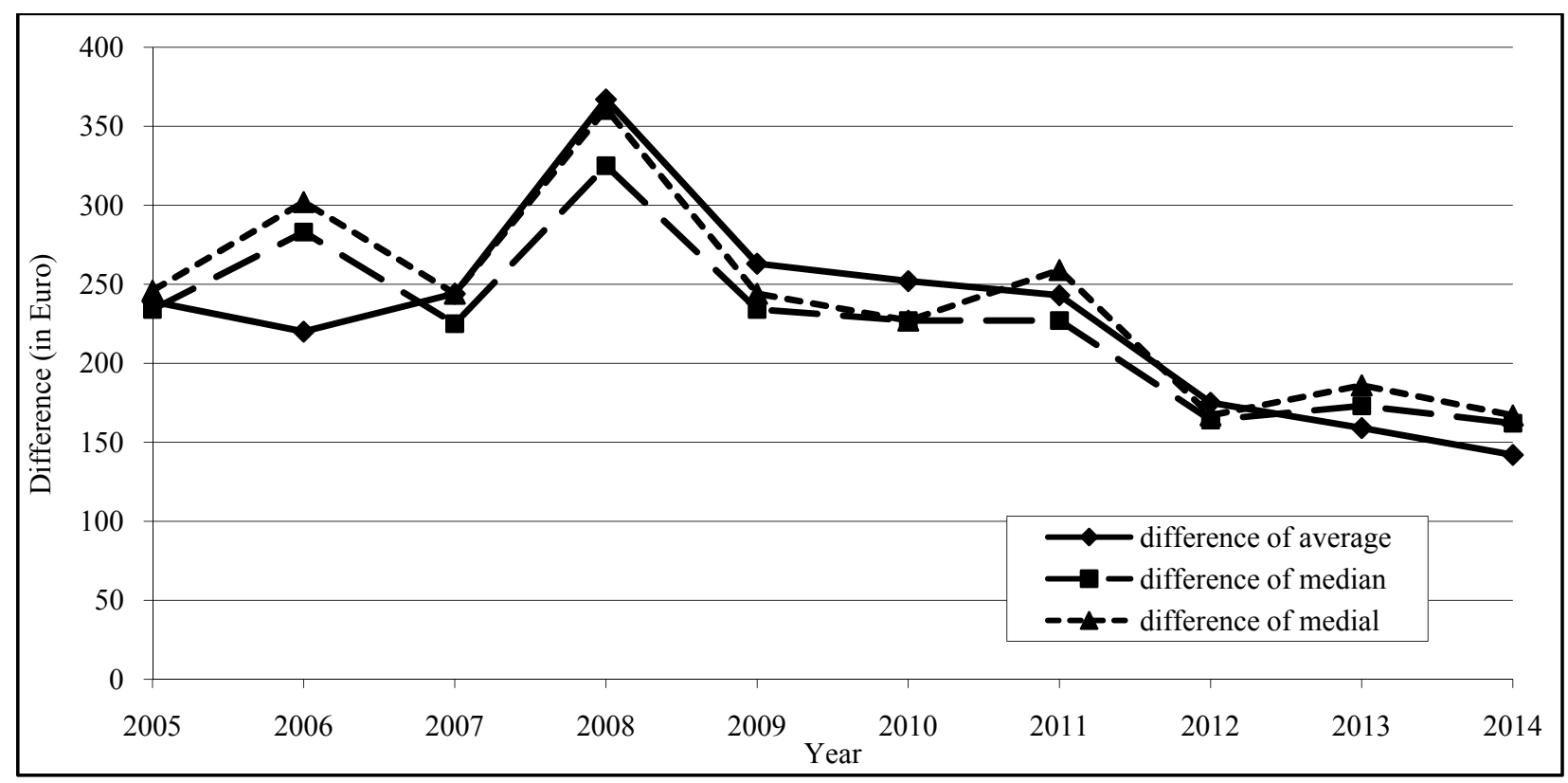

Figure 6. Differences of location characteristics of wage distribution between Czech and Slovak employees (total set) between 2005 and 2012 including predictions for 2013 and 2014. Source: Own research.

Figures 7 and 8 represent a different development of differences in wage levels between men and women in the Czech Republic and the Slovak Republic. We can observe from these figures that while the difference in wage levels between men and women in the Czech Republic is on a downward trend since the beginning of the financial crisis, the difference of wage levels between men and women in the Slovak Republic has a growing tendency even in times of global financial crisis, which is likely related to the increase in the level of wages in the Slovak Republic during the crisis. Difference in wage levels between men and women is now approximately the same in the Czech and Slovak Republics (see Figures 7-8).

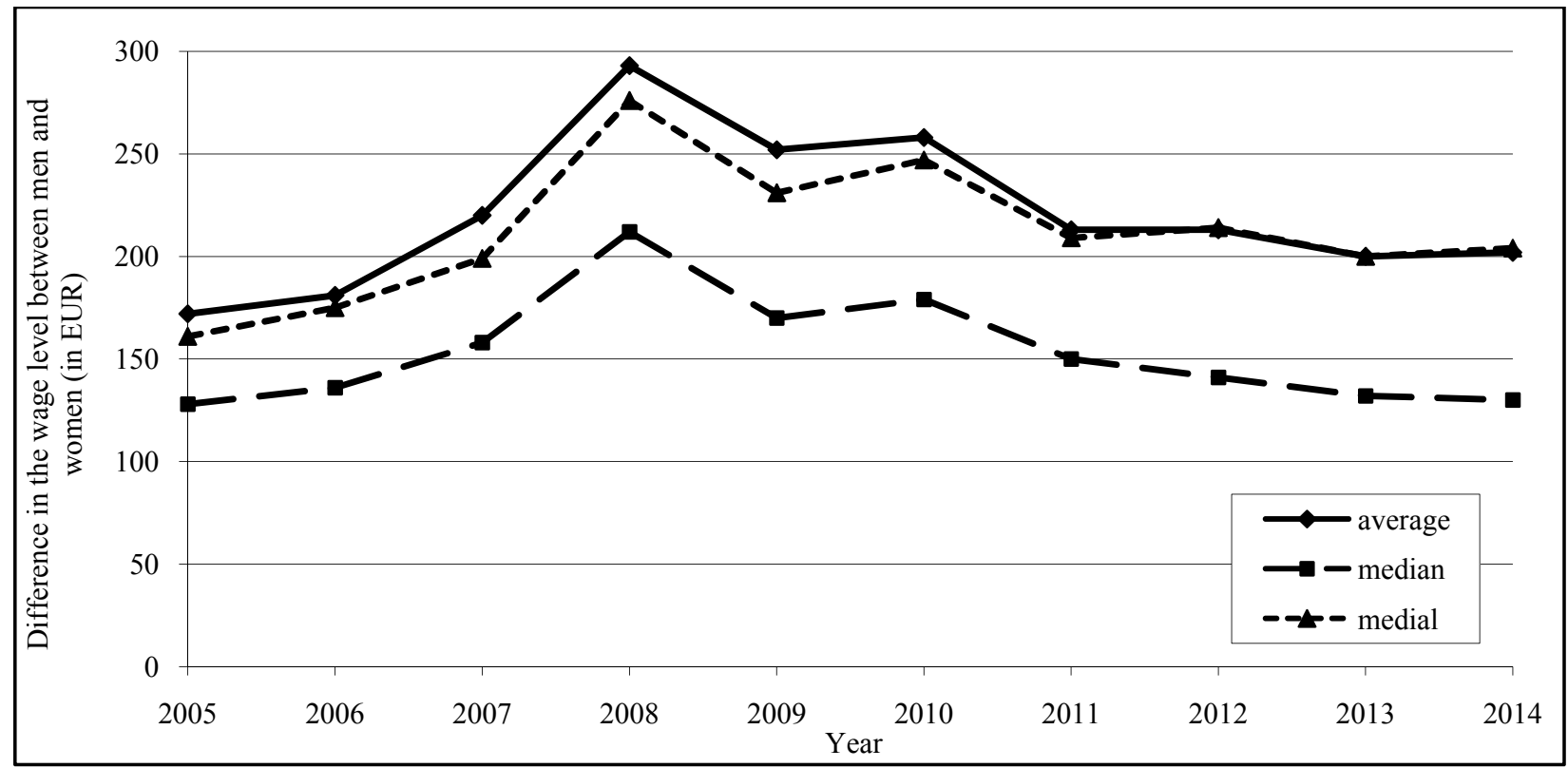

Figure 7. Differences in wage level (in EUR) between Czech men and women employees in the period of 2005-2012 including predictions for 2013 and 2014. Source: Own research. 


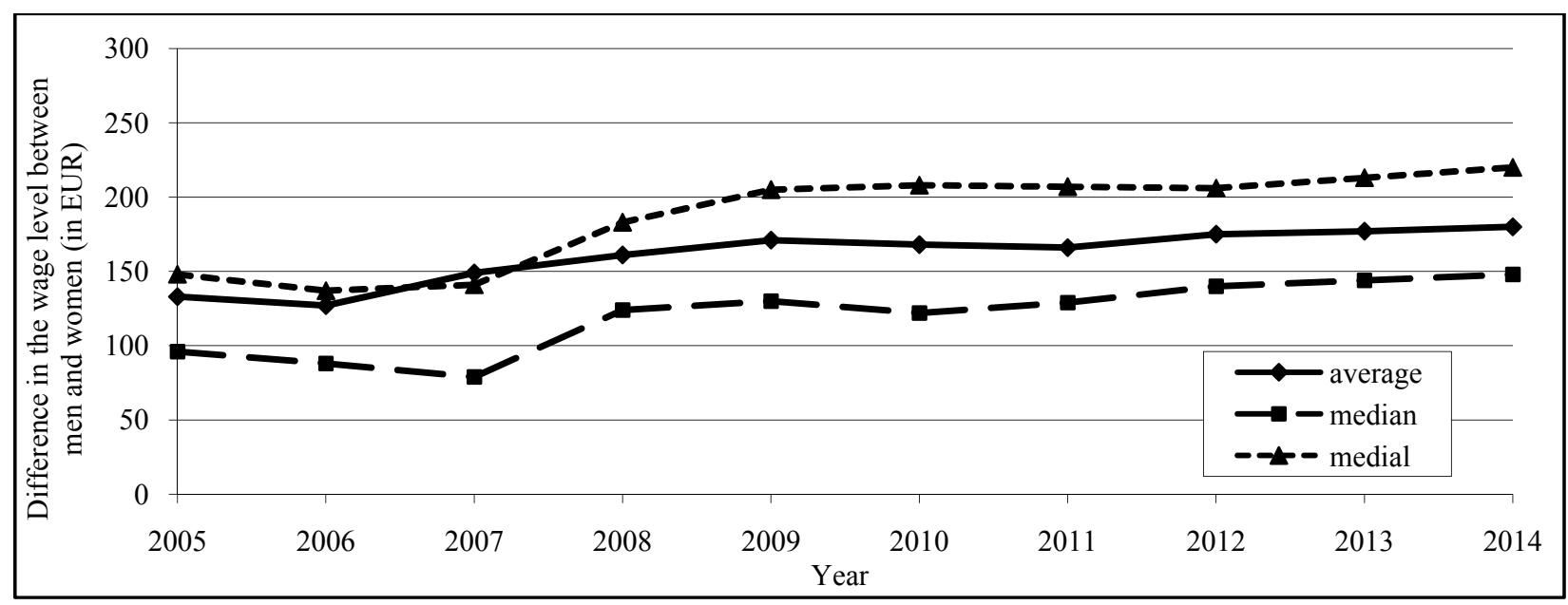

Figure 8. Differences in wage level (in EUR) between Slovak men and women employees in the period of 2005-2012 including predictions for 2013 and 2014. Source: Own research.

\section{Development of Wage Differentiation, Skewness, and Concentration}

Known characteristics of differentiation and skewness were used to describe the development of wage distributions of men and women in the Czech and Slovak Republics in the years of 2005-2012 (see Tables 5-6).

We observe an increasing absolute variability (standard deviation) of wages of Czech men and women in the period before the economic crisis, while the absolute variability of wages of Czech men and women rather fluctuates during the economic recession. Absolute variability of Slovak men and women grows all over the research period.

Because the absolute variability of wages increases with the level of wages, the use of relative characteristic (coefficient of variation) of wages is useful in this regard. While relative variability of wages of men and women in the Czech Republic has rather a growing trend in the whole monitored period, the relative variability of wages of men and women in the Slovak Republic has rather a downward tendency in this period. It is evident from the results that the global economic crisis does not considerably affect the wage distributions in terms of their relative variability in the Czech and Slovak Republics. Tables 5-6 provide an overview of the development of moment measure of skewness of wage distributions, too.

We can observe again the different behaviors of the wage distributions in terms of their concentration both between the Czech and Slovak Republics and between men and women in both countries (see Figure 9). While the concentration of total wage distribution in the Czech Republic for men and women together gradually increases with the exception of 2012, the concentration of total wage distribution in the Slovak Republic for men and women together is still approximately at the same level throughout the followed period (with a slightly decreasing trend). Although the concentration of this total wage distribution in the Czech Republic is sharply lower than in the Slovak Republic at the beginning of the research period, it is approximately at the same level at the end of this period. The concentration of wage distribution of men develops approximately the same way as the concentration of corresponding total wage distribution in the state (in both countries) (see Figure 9). In both countries, the concentration of wage distribution of women develops in very different ways from that of wage distribution of men, and it is approximately at the same level throughout the period, with slight fluctuations. However, it would be noted that the results may be again affected by the conversions from CZK to EUR and SKK to EUR at the beginning of the period. 
Table 5

Development of Sample Characteristics of Variation and Skewness of Gross Monthly Wage (Standard Deviation in EUR, Coefficient of Variation in \%, and Moment Measure of Skewness Without Unit) of Czech Employees in the Period of 2005-2012 by Gender

\begin{tabular}{lllllll}
\hline \multirow{2}{*}{ Year } & \multicolumn{2}{c}{ Men } & & \multicolumn{2}{c}{ Women } \\
\cline { 2 - 3 } & Standard deviation $\begin{array}{c}\text { Coefficient of } \\
\text { variation }\end{array}$ & Moment skewness & Standard deviation $\begin{array}{c}\text { Coefficient of } \\
\text { variation }\end{array}$ & Moment skewness \\
\hline 2005 & 390 & 50.65 & 2.052 & 306 & 51.17 & 0.877 \\
2006 & 424 & 49.94 & 1.947 & 337 & 50.45 & 0.855 \\
2007 & 564 & 60.65 & 2.868 & 408 & 57.46 & 1.914 \\
2008 & 717 & 59.65 & 2.717 & 523 & 57.54 & 1.728 \\
2009 & 675 & 60.81 & 2.673 & 490 & 57.11 & 1.721 \\
2010 & 680 & 60.28 & 2.610 & 493 & 56.67 & 1.706 \\
2011 & 717 & 63.90 & 2.426 & 519 & 57.10 & 1.777 \\
2012 & 683 & 62.83 & 2.480 & 498 & 56.98 & 1.838 \\
\hline
\end{tabular}

Note. Source: Own research.

Table 6

Development of Sample Characteristics of Variation and Skewness of Gross Monthly Wage (Standard Deviation in EUR, Coefficient of Variation in \%, and Moment Measure of Skewness Without Unit) of Slovak Employees in the Period of 2005-2012 by Gender

\begin{tabular}{lllllll}
\hline \multirow{2}{*}{ Year } & \multicolumn{2}{c}{ Men } & & \multicolumn{2}{c}{ Women } \\
\cline { 2 - 3 } & Standard deviation $\begin{array}{l}\text { Coefficient of } \\
\text { variation }\end{array}$ & Moment skewness & & Standard deviation $\begin{array}{c}\text { Coefficient of } \\
\text { variation }\end{array}$ & Moment skewness \\
\hline 2005 & 347 & 66.35 & 2.630 & 227 & 58.21 & 2.626 \\
2006 & 364 & 67.66 & 2.578 & 248 & 60.34 & 2.659 \\
2007 & 431 & 64.81 & 2.408 & 306 & 59.30 & 2.465 \\
2008 & 495 & 62.82 & 2.259 & 364 & 58.05 & 2.168 \\
2009 & 517 & 63.13 & 2.182 & 373 & 57.56 & 2.047 \\
2010 & 527 & 62.59 & 2.077 & 385 & 57.12 & 1.921 \\
2011 & 527 & 61.14 & 2.042 & 393 & 56.47 & 1.885 \\
2012 & 531 & 58.93 & 2.029 & 395 & 54.41 & 1.821 \\
\hline
\end{tabular}

Note. Source: Own research.

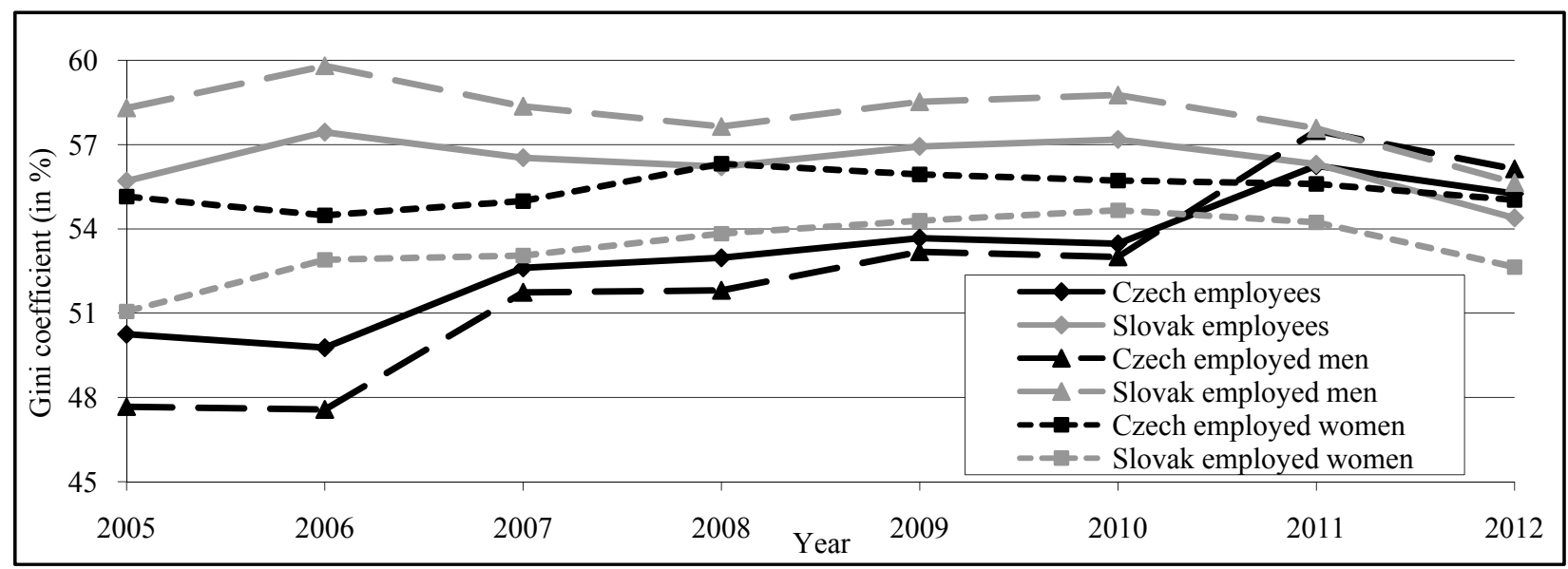

Figure 9. Development of Gini coefficient of concentration (in \%) of Czech and Slovak employees in the period of 2005-2012 by gender. Source: Own research. 


\section{Conclusion}

The wage distribution of men and women in the Czech and Slovak Republics changes over time. Their absolute amount grows with relatively fast pace in the period before the global economic crisis (2005-2008). Wage growth in the Czech Republic has virtually stopped in the period immediately after the onset of economic recession. But it can be stated here that this stopping in the wage growth in the Czech Republic is caused mainly by the development of the exchange rate CZK/EUR and it is not caused by the decrease of nominal wage. Later, this sharp impact of the economic recession on wage growth eases in the Czech Republic in both genders, and absolute wage levels begin to rise again (with the exception of 2012), but it is far below the rate of growth before the crisis. In contrast, in the Slovak Republic, wage growth continues despite the period of economic recession in both genders, although wage growth has noticeably slowed down during the financial crisis. Although the level of nominal wages in the Czech Republic is still strongly higher than in the Slovak Republic, Slovak wages are closer to the level of Czech wages due to the different responses of gross monthly wage in connection with the onset of economic recession in the Czech and Slovak Republics since the start of the financial crisis.

\section{References}

Bílková, D. (2012a). Modelling of wage and income distributions using the method of L-moments. Journal of Mathematics and System Science, 2, 13-19.

Bílková, D. (2012b). Lognormal distribution parameter estimating using L-moments. Journal of Mathematics and Technology, 3(1), 33-51.

Hosking, J. R. M., \& Wallis, J. R. (1997). Regional frequency analysis: An approach based on L-moments. New York, NY: Cambridge University Press.

Kyselý, J., \& Picek, J. (2007). Regional growth curves and improved design value estimates of extreme precipitation events in the Czech Republic. Climate Research, 33(3), 243-255.

Löster, T., \& Langhamrová, J. (2011). Analysis of long-term unemployment in the Czech Republic. Retrieved from http://msed.vse.cz/files/2011/Loster.pdf

Löster, T., \& Langhamrová, J. (2012). Disparities between regions of the Czech Republic for non-business aspects of labour market. Retrieved from http://msed.vse.cz/files/2012/Loster_2012.pdf

Löster, T., \& Pavelka, T. (2013). Evaluating of the results of clustering in practical economic tasks. Retrieved from http://msed.vse.cz/files/2013/228-Loster-Tomas-paper.pdf

Malec, L., \& Malec, M. (2013). Application of two-set multivariate statistical methods to the Czech Republic arrival tourism data. Retrieved from http://msed.vse.cz/files/2013/163-Malec-Lukas-paper.pdf

Marek, L. (2010). Analýza vývoje mezd v ČR v letech 1995-2008. Politická ekonomie, 58(2), 186-206.

Marek, L. (2013). Some aspects of average wage evolution in the Czech Republic. Retrieved from http://msed.vse.cz/files/2013/208-Marek-Lubos-paper.pdf

Marek, L., \& Vrabec, M. (2013). Probability models for wage distributions. In Mathematical methods in economics 2013 (pp. 575-581). Jihlava: College of Polytechnics.

Marek, L., \& Vrabec, M. (2014). Mixture of Johnson distribution. In Quantitative methods in economics (Multiple criteria decision making XVII) (pp. 162-170). Bratislava: EKONÓM.

Pivoňka, T., \& Löster, T. (2013). Clustering of EU countries before and during crisis. Retrieved from http://msed.vse.cz/files/2013/87-Pivonka-Tomas-paper.pdf

Řezanková, H., \& Löster, T. (2013). Shluková analýza domácností charakterizovaných kategoriálními ukazateli. E+M Ekonomie a Management, 16, 139-147.

Triola, M. F. (2003). Elementary statistics. Boston: Addison Wesley. 